\title{
Correction to: On the application of the Two-Factor Theory to online employer reviews
}

\author{
Philipp Koncar $^{1}$ (D) $\cdot$ Tiago Santos $^{2} \cdot$ Markus Strohmaier $^{3} \cdot$ Denis Helic $^{1}$
}

Published online: 10 January 2022

(c) The Author(s) 2022

\section{Correction to: Journal of Data, Information and Management} https://doi.org/10.1007/s42488-021-00061-3

In the original article, the affiliation details were incorrectly assigned. The correct affiliation details should read as follows:

Philipp Koncar: Graz University of Technology, Graz, Austria

Tiago Santos: Energie Steiermark AG, Graz, Austria

Markus Strohmaier: RWTH Aachen University, Aachen, Germany

Denis Helic: Graz University of Technology, Graz, Austria

The original article has been corrected.
Open Access This article is licensed under a Creative Commons Attribution 4.0 International License, which permits use, sharing, adaptation, distribution and reproduction in any medium or format, as long as you give appropriate credit to the original author(s) and the source, provide a link to the Creative Commons licence, and indicate if changes were made. The images or other third party material in this article are included in the article's Creative Commons licence, unless indicated otherwise in a credit line to the material. If material is not included in the article's Creative Commons licence and your intended use is not permitted by statutory regulation or exceeds the permitted use, you will need to obtain permission directly from the copyright holder. To view a copy of this licence, visit http://creativecommons.org/licenses/by/4.0/.

Publisher's note Springer Nature remains neutral with regard to jurisdictional claims in published maps and institutional affiliations.

The online version of the original article can be found at https:// doi.org/10.1007/s42488-021-00061-3

Philipp Koncar

koncar@tuta.io

Tiago Santos

tsantos.tugraz@gmail.com

Markus Strohmaier

markus.strohmaier@cssh.rwth-aachen.de

Denis Helic

dhelic@tugraz.at

1 Graz University of Technology, Graz, Austria

2 Energie Steiermark AG, Graz, Austria

3 RWTH Aachen University, Aachen, Germany 